\title{
Analisis Risiko Pada Return Saham Perusahaan Asuransi Menggunakan Metode VaR dengan Pendekatan ARMA-GARCH
}

\author{
Endy Normacinthya Damayanti ${ }^{\left({ }^{*}\right)}$, Heri Kuswanto ${ }^{\left(2^{*}\right)}$
}

\begin{abstract}
Indonesia's capital market is one of the investment destination countries for investors in developed markets, known as emerging markets. The development of economic conditions in Indonesia itself is considered good for investors to invest. Financial sector shares are one of the sectors that have developed throughout the year. Three of the seven stocks that showed good growth were PT Multi Artha Guna Tbk (AMAG), PT Paninvest Tbk (PNIN), and PT Lippo General Insurance Tbk (LPGI). In term of investation, there are two important things, namely the rate of return and risk. Another important component is the volatility of stock returns. This research analyzes stock returns and the volatility of the three stocks. The method used in estimating stock risk is VaR (Value at Risk). MA and GARCH can be used to overcome volatility. It was found that three company shares gave a positive average return value to provide benefits for investors. LPGI company shares have the highest potential risk because of the high standard deviation value. The best model for AMAG stock returns is ARMA ([7], [7]) and GARCH $(1,2)$. The best model for LPGI stock returns are ARMA ([2], [2]) and GARCH $(1,1)$. PNIN stock returns obtained the best models ARMA $(0,[3])$ and GARCH $(1,2)$. To simplify the interpretion ARMA $(1,0)$ GARCH $(1,1)$ model is obtained for AMAG company stock returns, ARMA $(0,1)$ GARCH $(1,1)$ for LPGI and ARMA $(1,1)$ GARCH company stock returns $(1,1)$ for PNIN company stock returns. The calculation of VaR showed that investors will experience a maximum loss of Rp. 47,089,529, - if they invest Rp. 1,000,000,000, - in AMAG companies, it also applies to LPGI companies, investors will incur a loss of Rp. 60,018,734 and Rp. 39,196 .540, - in a PNIN company with a $95 \%$ confidence level.
\end{abstract}

Keywords : ARMA-GARCH, Stock, Value at Risk

\begin{abstract}
Abstrak
Pasar modal Indonesia merupakan salah satu negara tujuan investasi bagi investor di negara-negara maju (developed markets) yang dikenal sebagai emerging market. Perkembangan kondisi perekonomian di Indonesia sendiri dianggap baik bagi para investor untuk menanamkan dana. Saham sektor keuangan menjadi salah satu sektor yang ikut berkembang di sepanjang tahun ini. Tiga dari tujuh saham yang menunjukkan bertumbuh dengan baik adalah PT Asuransi Multi Artha Guna Tbk (AMAG), PT Paninvest Tbk (PNIN), dan PT Lippo General Insurance Tbk (LPGI). Terdapat dua hal penting yaitu tingkat pengembalian atau imbal hasil (return) dan risiko. Komponen lain yang tidak kalah penting adalah volatilitas return saham. Berdasarkan penjelasan diatas, maka dilakukan penelitian untuk menganalisis return saham dan volatilitas ketiga saham. Salah satu metode yang digunakan dalam mengestimasi risiko saham adalah metode VaR (Value at Risk). Untuk mengatasi volatilitas dapat menggunakan ARMA dan GARCH. Dihasilkan bahwa tiga saham perusahaan memberikan nilai rata-rata return yang positif sehingga memberikan keuntungan bagi investor. Saham perusahaan LPGI memiliki potensi risiko yang paling tinggi karena nilai standar deviasi yang tinggi. Model terbaik untuk return saham AMAG adalah ARMA ([7],[7]) dan model GARCH $(1,2)$. Pada return saham LPGI model terbaik adalah ARMA ([2],[2]) dan GARCH $(1,1)$. Return saham PNIN diperoleh model terbaik ARMA $(0,[3])$ dan GARCH $(1,2)$. Pada pemodelan Parsimony didapatkan model ARMA $(1,0)$ GARCH $(1,1)$ untuk return saham perusahaan AMAG, ARMA $(0,1)$ GARCH $(1,1)$ untuk return saham perusahaan LPGI dan ARMA $(1,1)$ GARCH $(1,1)$ untuk return saham perusahaan PNIN. Pada perhitungan VaR didapatkan investor akan mengalami kerugian maksimum sebesar Rp 47.089.529,- bila menanamkan modal sebesar Rp 1.000.000.000,- di perusahaan AMAG, berlaku pula pada perusahaan LPGI, investor akan mengalami kerugian sebesar Rp 60.018.734,- dan Rp 39.196.540,- di perusahaan PNIN dengan tingkat keyakinan 95\%.
\end{abstract}

*Jurusan Statistika, Fakultas MIPA, Institut Teknologi Sepuluh Nopember (ITS)

$\mathrm{Jl}$. Arief Rahman Hakim, Surabaya 60111 Indonesia

e-mail:heri_k@statistika.its.ac.id ${ }^{(2)}$,endy.norma@gmail.com ${ }^{(1)}$ 


\section{Kata Kunci : ARMA-GARCH, Saham, Value at Risk}

\section{PENDAHULUAN}

Pasar modal Indonesia merupakan salah satu negara tujuan investasi bagi investor di negaranegara maju (developed markets) yang dikenal sebagai emerging market. Perkembangan kondisi perekonomian di Indonesia sendiri dianggap baik bagi para investor untuk menanamkan dana. Sejak keberadaan pasar modal Indonesia yang terus membaik, peranan investor asing terus meningkat, baik dari segi dana yang masuk maupun dari pelakunya. Ada banyak faktor yang mempengaruhi minat investasi di suatu negara antara lain faktor keamanan, stabilitas sosial dan politik, dan sebagainya [1]. Salah satu contoh keberadaan pasar modal Indonesia yang terus membaik adalah PT Aneka Tambang Tbk (ANTM). Pertumbuhan kinerja perusahaan dapat terlihat dari transaksi yang sangat aktif, memiliki pertumbuhan harga saham yang signifikan, dan memiliki fundamental yang sehat [2]. Saham sektor keuangan juga menjadi salah satu sektor yang ikut berkembang di sepanjang tahun ini. Pertumbuhannya mencapai 7,76 persen. Setidaknya ada 7 perusahaan yang sahamnya bertumbuh baik. Tiga dari tujuh saham yang menunjukkan bertumbuh dengan baik adalah PT Asuransi Multi Artha Guna Tbk (AMAG), PT Paninvest Tbk (PNIN), dan PT Lippo General Insurance Tbk (LPGI). Saham AMAG meningkat 30,48 persen dari posisi akhir 2016 Rp 374 menjadi Rp 488. Pergerakan ini membawa saham induknya yaitu PT Paninvest Tbk (PNIN) ikut bergerak dengan catatan tumbuh 19,01 persen dari Rp 605 menjadi Rp 720. Sedangkan PT Lippo General Insurance Tbk (LPGI) meningkat sebesar 5,56 persen dari posisi akhir 2016 Rp 5400 menjadi Rp 5700 [3].

Berdasarkan kondisi ketiga saham asuransi yang terpaparkan sehingga dalam berinvestasi khususnya pada saham, terdapat dua hal penting yaitu tingkat pengembalian atau imbal hasil (return) dan risiko. Komponen lain yang tidak kalah penting adalah volatilitas return saham. Volatilitas berarti conditional variance (varians dinamik) dari sebuah asset. Volatilitas ini digunakan dalam memprediksi risiko [4]. Berdasarkan penjelasan diatas, maka dilakukan penelitian untuk menganalisis return saham dan volatilitas ketiga saham yang bergerak di bidang asuransi. Salah satu metode yang sering digunakan dalam mengestimasi risiko saham adalah metode VaR (Value at Risk). untuk mengatasi volatilitas tersebut dapat menggunakan Generalized Autoregressive Conditional Heteroskedasticity (GARCH). Dilibatkan adanya pengaruh waktu dalam pengukuran nilai risiko, maka pemodelan akan dilakukan dengan menggunakan pendekatan Autoregressive Moving Average (ARMA). Dengan demikian, pada penelitian ini akan melibatkan tiga saham perusahaan untuk mengetahui karakteristik, model terbaik dari pendekatan ARMA-GARCH, dan nilai risiko yang didasarkan pada tiga data return saham perusahaan.

\section{TINJAUAN PUSTAKA}

\section{a. Return dan Risiko Saham}

Invesatasi dengan membeli saham suatu perusahaan, berarti investor telah menginvestasikan dana dengan harapan akan mendapatkan keuntungan dari penjualan kembali saham tersebut. Data saham umumnya memiliki volatilitas yang tinggi. Return adalah keuntungan-keuntungan yang diperoleh oleh perusahaan, individu, ataupun institusi lain berdasarkan hasil investasi yang dilakukannya. Nilai return saham dapat dihitung menggunakan persamaan [5]

$$
R_{t}=\frac{P_{t}-P_{t-1}}{P_{t-1}}
$$

dengan $R_{t}$ adalah nilai return pada waktu ke- $t, P_{t}$ adalah harga saham pada waktu ke- $t$ dan $P_{t-1}$ adalah harga saham pada waktu ke-(t-1). Risiko merupakan perbedaan antara return aktual yang diterima dengan return yang diharapakan. 


\section{b. Uji Augmented Dickey Fuller}

Augmented Dickey Fuller (ADF) merupakan salah satu pengujian statistik yang digunakan untuk menguji kestasioneran data dalam mean. Uji ADF gunanya untuk mengakomodasi terjadinya korelasi pada residual dengan menambahkan lag-lag dari variabel dependen $Z_{t}$. Secara spesifik, uji ADF mengikuti estimasi regresi berikut [6].

$$
\Delta Z_{t}=\beta_{1}+\beta_{2} t+\delta Z_{t-1}+\sum_{j=1}^{p} \alpha_{j} \Delta Z_{t-j}+\varepsilon_{t}
$$

Uji ADF memliki hipotesis sebagai berikut.

$\mathrm{H}_{0}: \delta=0$ (data tidak stasioner)

$\mathrm{H}_{1}: \delta<0$ (data stasioner)

Statistik uji :

$$
T=\frac{\hat{\delta}}{S E(\hat{\delta})}
$$

$\mathrm{H}_{0}$ ditolak jika $T$ lebih kecil dari titik kritis $T^{*}$ pada tabel Dickey Fuller dan menunjukkan bahwa data telah stasioner dalam mean.

\section{c. Proses Autoregressive Moving Average (ARMA)}

ARMA merupakan penggabungan dari model AR dan MA yang merupakan proses yang menggambarkan kondisi $\mathrm{Z}_{\mathrm{t}}$ dipengaruhi kondisi sebelumnya dan diikitu $a_{t}$ yang bersifat white noise. Model matematis ARMA adalah sebagai berikut [5].

$$
Z_{t}=\mu+\phi_{1} Z_{t-1}+\phi_{2} Z_{t-2}+\ldots+\phi_{p} Z_{t-p}+a_{t}-\theta_{1} a_{t-1}-\theta_{2} a_{t-2}-\ldots-\theta_{q} a_{t-q}
$$

Tahap identifikasi model ARMA dilakukan dengan pemeriksaan plot Autocorrelation Function (ACF) dan Partial Autocorrelation Function (PACF). Formula untuk ACF adalah sebagai berikut

$$
\hat{\rho}_{k}=\frac{\sum_{t=k+1}^{n}\left(Z_{t}-\bar{Z}\right)\left(Z_{t-k}-\bar{Z}\right)}{\sum_{t=1}^{n}\left(Z_{t}-\bar{Z}\right)^{2}}
$$

PACF merupakan fungsi korelasi antara $\mathrm{Z}_{\mathrm{t}}$ dan $\mathrm{Z}_{\mathrm{t}-\mathrm{k}}$. Formula untuk PACF dapat dilihat pada berikut.

$$
\begin{aligned}
\rho_{k} & =\operatorname{corr}\left(Z_{t}, Z_{t-k} \mid Z_{t+1}, \ldots, Z_{t-k+1}\right), \\
& =\frac{\operatorname{cov}\left[\left(Z_{t}-\hat{Z}_{t}\right)\left(Z_{t-k}-\hat{Z}_{t-k}\right)\right]}{\sqrt{\operatorname{var}\left(Z_{t}-\hat{Z}_{t}\right)} \sqrt{\operatorname{var}\left(Z_{t-k}-\hat{Z}_{t-k}\right)}}
\end{aligned}
$$

Setelah menetapkan model sementara, langkah selanjutnya adalah menaksir parameter model yang terbentuk. Terdapat beberapa metode yang digunakan dalam menaksir parameter, antara lain metode Momen, Maximum Likelihood Estimation (MLE), Nonlinear Estimation dan Least Square. Metode penaksiran parameter yang biasa digunakan adalah metode Conditional Least Square (CLS). Metode ini dilakukan dengan cara mencari nilai parameter yang meminimumkan jumlah kuadrat error/SSE [7]. Misalkan untuk model AR(1), maka least square estimation sebagai berikut.

$$
S\left(\phi_{1}, \mu\right)=\sum_{t=2}^{n} a_{t}^{2}=\sum_{t=2}^{n}\left[\left(Z_{t}-\mu\right)-\phi_{1}\left(Z_{t-1}-\mu\right)\right]^{2}
$$

Berdasarkan metode least square, taksiran $\phi_{1}$ dan $\mu$ dengan meminimumkan $S\left(\phi_{1}, \mu\right)$. Oleh karena itu, perlu dilakukan differential terhadap $\phi_{1}$ dan $\mu$ kemudian disamakan dengan nol. Berikut merupakan operasi turunan terhadap $\mu$.

$$
\frac{\partial S}{\partial \mu}=\sum_{t=2}^{n} 2\left[\left(Z_{t}-\mu\right)-\phi_{1}\left(Z_{t-1}-\mu\right)\right]\left(-1+\phi_{1}\right)=0
$$

Sehingga taksiran parameter $\mu$ untuk model AR (1) adalah sebagai berikut.

$$
\mu=\frac{1}{(n-1)\left(1-\phi_{1}\right)}\left[\sum_{t=2}^{n} Z_{t}-\phi_{1} \sum_{t=2}^{n} Z_{t-1}\right]
$$

Sedangkan untuk n yang sangat besar, persamaan (9) menjadi sebagai berikut. 


$$
\frac{1}{n-1} \sum_{t=2}^{n} Z_{t} \approx \frac{1}{n-1} \sum_{t=2}^{n} Z_{t-1} \approx \bar{Z}
$$

Selanjutnya, persamaan (10) disederhanakan menjadi

$$
\hat{\mu} \approx \frac{1}{\left(1-\phi_{1}\right)}\left(\bar{Z}-\phi_{1} \bar{Z}\right)=\bar{Z}
$$

Kemudian untuk parameter $\phi_{1}$ dengan cara yang sama didapatkan operasi turunan sebagai berikut.

$$
\frac{\partial S\left(\phi_{1}, \bar{Z}\right)}{\partial \phi_{1}}=\sum_{t=2}^{n} 2\left[\left(Z_{t}-\bar{Z}\right)-\phi_{1}\left(Z_{t-1}-\bar{Z}\right)\right]\left(Z_{t-1}-\bar{Z}\right)=0
$$

Sehingga taksiran parameter $\phi_{1}$ untuk model AR (1) adalah sebagai berikut.

$$
\hat{\phi}=\frac{\sum_{t=2}^{n}\left(Z_{t}-\bar{Z}\right)\left(Z_{t-1}-\bar{Z}\right)}{\sum_{t=2}^{n}\left(Z_{t-1}-\bar{Z}\right)^{2}}
$$

Pengujian parameter dilakukan dengan tujuan untutk mementukan apakah parameter model sudah layak masuk kedalam model dengan hipotesis sebagai berikut.

$\mathrm{H}_{0}: \phi_{j}=0$ (parameter tidak signifikan)

$\mathrm{H}_{1}: \phi_{j} \neq 0$ (parameter signifikan), dengan $\mathrm{j}=1,2,3, \ldots, \mathrm{p}$

Statistik Uji:

$$
t_{\text {hitung }}=\frac{\hat{\phi}_{j}}{\operatorname{SE}\left(\hat{\phi}_{j}\right)}
$$

$\mathrm{H}_{0}$ ditolak jika $t_{\text {hitung }}$ lebih besar $t_{1-\frac{\alpha}{2}, n-n_{p}}$ dengan $\mathrm{n}_{\mathrm{p}}=$ banyaknya parameter.

Pengujian asumsi white noise menggunakan uji Ljung-Box dengan hipotesis sebagai berikut.

$\mathrm{H}_{0}: \rho_{1}=\rho_{2}=\ldots=\rho_{K} \quad$ (Antar residual white noise)

$\mathrm{H}_{1}$ : minimal ada satu nilai $\rho_{k} \neq 0$ dimana $k=1,2,3, \ldots, K$ (antar residual tidak white noise)

Statistik Uji:

$$
Q=n(n+2) \sum_{k=1}^{K}(n-k)^{-1} \hat{\rho}_{k}^{2}
$$

$\mathrm{H}_{0}$ ditolak jika $Q$ lebih besar $\chi_{\alpha, K-p-q}^{2}$, dimana nilai $p$ dan $q$ adalah orde dari $\operatorname{ARMA}(p, q)$.

Uji Kolmogorov Smirnov [9] digunakan untuk mengetahui bahwa residual data memenuhi asumsi distribusi normal. Berikut adalah pengujian asumsi residual berdistribusi normal.

Hipotesis :

$\mathrm{H}_{0}: \mathrm{F}(\mathrm{x})=\mathrm{F}_{0}(\mathrm{x})$ (residual berdistribusi normal)

$\mathrm{H}_{1}: \mathrm{F}(\mathrm{x}) \neq \mathrm{F}_{0}(\mathrm{x})$ (residual tidak berdistribusi normal)

Statistik uji :.

$$
D=\sup \left|S(x)-F_{0}(x)\right|
$$

Apabila nilai $\mathrm{D}_{\text {hitung }}$ lebih besar $\mathrm{D}_{(1-\alpha, \mathrm{n})}$, maka tolak $\mathrm{H}_{0}$ yang artinya residual tidak berdistribusi normal.

Pemilihan model terbaik menggunakan kriteria AIC (Akaike'e Information Criterion) dan Scwartz's Bayesian Criterion (SBC) dengan persamaan.

$$
\begin{aligned}
& A I C(M)=n \ln \hat{\sigma}_{\alpha}^{2}+2 M \\
& S B C(M)=n \ln \hat{\sigma}_{\alpha}^{2}+M \ln n
\end{aligned}
$$

\section{d.Generalized Autoregresive Conditional Heteroskedasticity (GARCH)}

Model GARCH (Generalized Autoregressive Conditional Heteroscedasticity) adalah salah satu model ekonometrik yang diperkenalkan oleh [10]. Pendekatan pada metode ini adalah autoregressive 
karena GARCH pada dasarnya adalah model time series dengan bentuk autoregressive dan disebut conditional heteroscedasticity karena variasi waktu pada varians bersyarat dibangun pada model tersebut. GARCH merupakan bentuk umum atau generalisasi dari Autoregressive conditional Heteroscedastisity (ARCH).

$$
\sigma_{t}^{2}=\omega+\sum_{i=1}^{r} \varphi_{i} \varepsilon_{t-i}^{2}+\sum_{j=1}^{s} \beta_{j} \sigma_{t-j}^{2}
$$

Identifikasi model GARCH dilakukan dengan melakukan uji LM (Lagrage Multiplier) dengan hipotesis sebagai berikut.

Hipotesis :

$\mathrm{H}_{0}: \varphi_{1}=\varphi_{2}=\ldots=\varphi_{r}=0$ (tidak terdapat efek ARCH-GARCH)

$\mathrm{H}_{1}$ : Minimal ada satu $\varphi_{i} \neq 0$ untuk $\mathrm{i}=1,2, \ldots, \mathrm{r}$ (terdapat efek ARCH-GARCH)

Statistik Uji :

$$
L M=n R^{2}
$$

\section{e. Value at Risk (VaR)}

VaR merupakan konsep perhitungan risiko yang dikembangkann dari konsep kurva normal. VaR bertujuan untuk menghitung tingkat keuntungan atau kerugian suatu investasi dalam waktu yang relatif dekat. Nilai VaR terbagi menjadi dua yaitu nilai VaR positif dan nilai VaR negatif. VaR yang bernilai positif menunjukkan bahwa perusahaan mendapatkan keuntungan dari kegiatan investasi saham sedangkan $\mathrm{VaR}$ yang bernilai negatif menunjukkan bahwa perusahaan mengalami kerugian dalam berinvestasi.

$$
\operatorname{VaR}(\tau)=\hat{\mu}_{t}+\hat{\sigma}_{t} F^{-1}(\tau)
$$

\section{METODOLOGI PENELITIAN}

\section{a.Sumber Data}

Sumber data yang digunakan dalam penelitian ini yaitu menggunakan data sekunder yang diperoleh dari finance.yahoo.com. Data yang diambil merupakan data harga saham close harian perusahaan sektor asuransi yang termasuk dalam Bursa Efek Indonesia (BEI) yaitu Asuransi Multi Artha Guna Tbk. (AMAG), Lippo General Insurance Tbk. (LPGI), dan Paninvest Tbk. (PNIN). Data ketiga perusahaan tersebut diambil dari 01 Januari 2010 - 28 April 2017.

\section{b.Variabel Penelitian}

Variabel yang digunakan dalam penelitian ini terdiri dari variabel respon yaitu data return saham harian sektor asuransi yaitu AMAG.JK, LPGI.JK, dan PNIN.JK.

\section{c. Langkah Analisis}

Langkah-langkah analisis yang diguanakan dalam penelitian ini adalah dengan metode VaR secara univarat dengan pendekatan ARMA-GARCH.

1. Menghitung nilai realized return di setiap saham perusahaan.

2. Mendeskripsikan return perusahaan secara statistik untuk mengetahui karakteristik data return.

3. Menguji stasioneritas data return dengan menggunakan uji Dickey Fuller

4. Melakukan uji signifkansi parameter dan uji diagnose residual pada model ARIMA yang terbentuk.

5. Menguji residual dari model ARIMA yang terbaik menggunakan uji Lagrange Multiplier

6. Melakukan pendugaan model ARCH-GARCH dan melakukan uji signifikansi parameter dan uji diagnose residual pada model ARCH-GARCH yang terbentuk. Selanjutnya dipilih model ARCH-GARCH yang terbaik dari nilai AIC dan SBC yang terkecil.

7. Menghitung nilai Value at Risk dengan beberapa lamanya waktu investasi yaitu satu hari pada model ARCH-GARCH saham.

8. Membuat kesimpulan dari hasil perhitungan Value at Risk 


\section{ANALISIS DAN PEMBAHASAN}

\section{a. Karakteristik Saham Perusahaan Sektor Asuransi}

Harga saham close pada perusahaan AMAG, LPGI, dan PNIN dapat disajikan dalam bentuk time series plot pada Gambar 1 sebagai berikut.
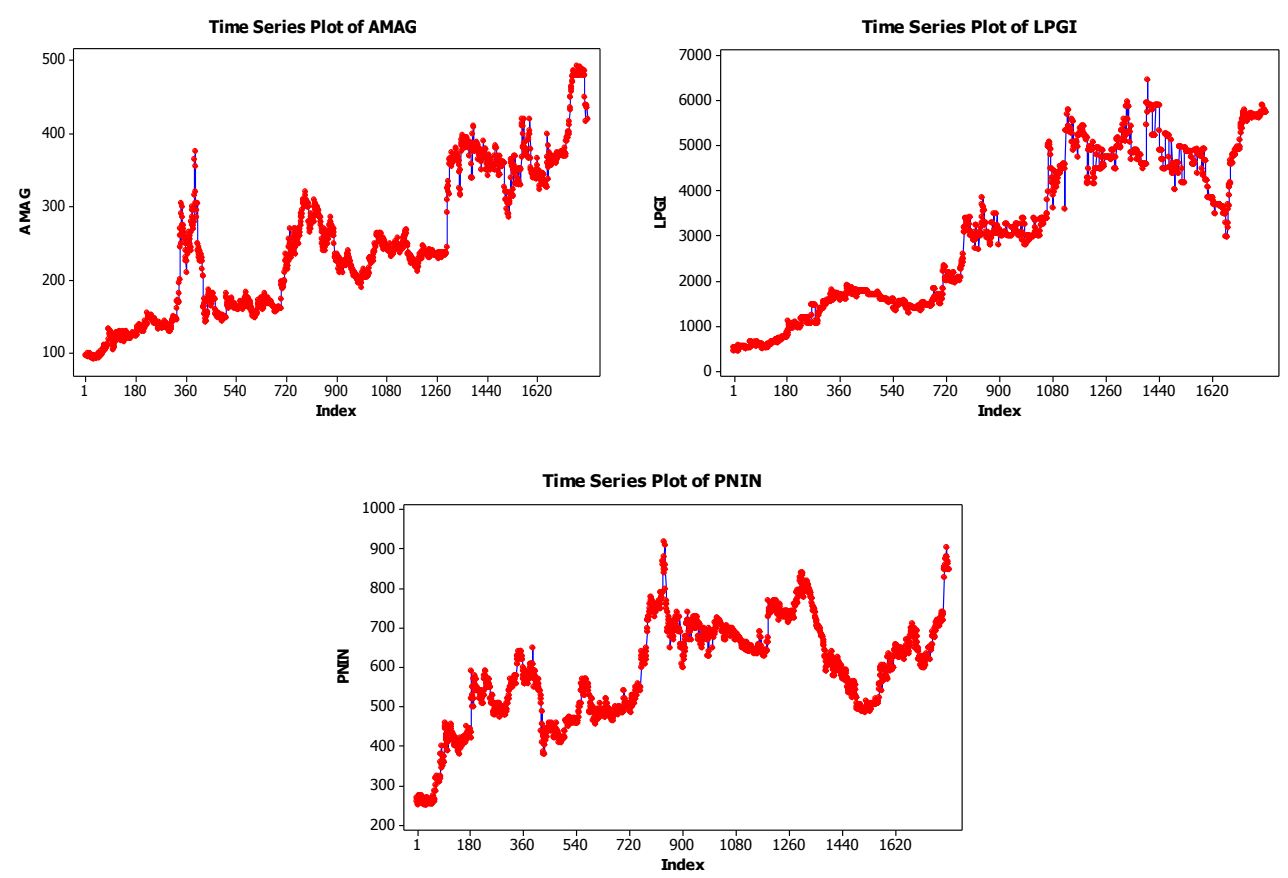

Gambar 1 Time Series Plot Harga Saham Close AMAG, LPGI, dan PNIN

Berdasarkan Gambar 1 diketahui bahwa ketiga perusahaan tersebut hampir memiliki pola yang sama. Pola yang mengalami penurunan sama tersebut terjadi pada kuartal pertama 2016. Hal ini dikarenakan pada saat periode tersebut jumlah laba yang didapat perusahaan asuransi pada saat itu mengalami penurunan. Penurunan laba terjadi karena underwriting perusahaan asuransi berpotensi lebih kecil dibandingkan tahun sebelumnya karena adanya peningkatan klaim. Selain penurunan laba, tingkat suku bunga yang juga menurun menyebabkan harga saham perusahaan asuransi turun pada saat itu. Semakin tinggi tingkat suku bunga, maka investor akan menjual sahamnya untuk ditukarkan dengan obligasi. Hal ini akan menurunkan harga saham.
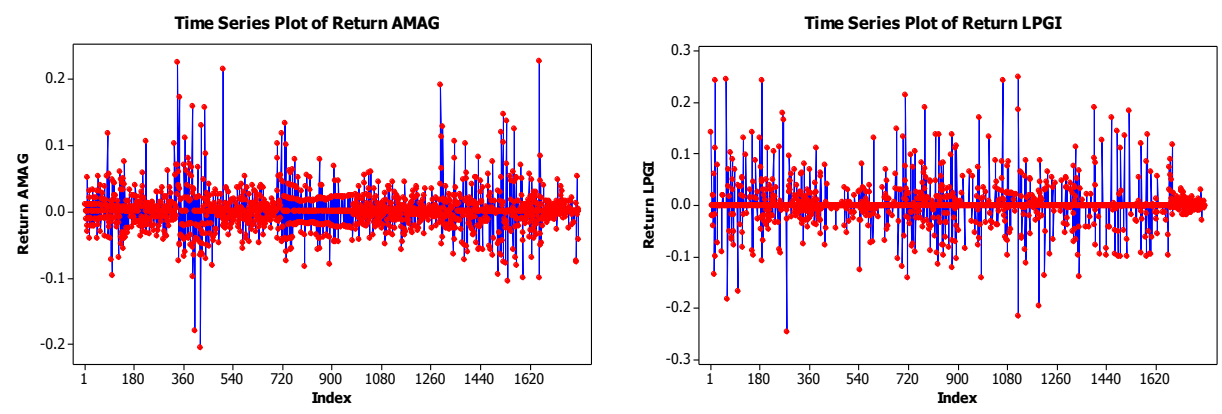


\section{Endy Normacinthya Damayanti, Heri Kuswanto}

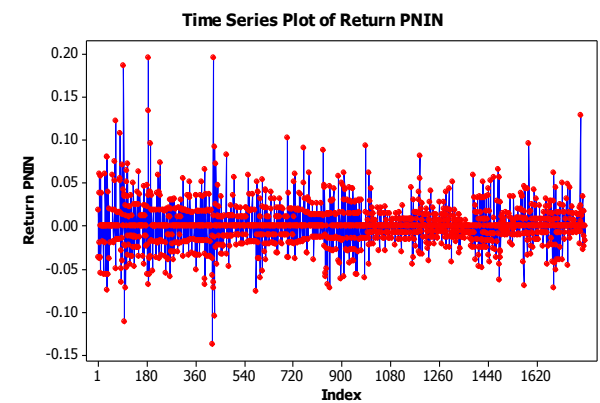

Gambar 2 Time Series Plot Return Saham AMAG, LPGI, dan PNIN

Time series plot return harian saham dapat dilihat pada Gambar 2 yang menggambarkan bahwa return harian saham mengalami fluktuasi dari waktu ke waktu. Fluktuasi terjadi karena kenaikan dan penurunan return saham harian (volatilitas). Apabila dilihat secara visual, saham yang mempunyai volatilitas yang tinggi adalah saham LPGI. Hal ini terlihat dari fluktuasi yang tejadi cukup lama. Berdasarkan time series plot dapat diketahui bahwa data return telah stasioner dalam mean. Karakteristik data return harian saham juga dapat dijelaskan dengan statistika deskriptif pada Tabel 1.

Tabel 1 Statistika Deskriptif Return Saham

\begin{tabular}{lrrrrrr}
\hline Variabel & Mean & StDev & Min. & Maks. & Skew. & \multicolumn{1}{c}{ Kurt. } \\
\hline AMAG & 0,001 & 0,030 & $-0,205$ & 0,227 & 1,190 & 10,770 \\
LPGI & 0,002 & 0,038 & $-0,247$ & 0,250 & 1,010 & 11,970 \\
PNIN & 0,001 & 0,025 & $-0,137$ & 0,195 & 1,110 & 9,180 \\
\hline
\end{tabular}

Selama periode Januari 2010 sampai Maret 2017 ketiga saham perusahaan tersebut memberikan nilai rata-rata return yang positif. Nilai return yang positif menandakan bahwa ketiga saham perusahaan memberikan keuntungan bagi investor. Diantara tiga saham perusahaan, saham perusahaan LPGI memiliki potensi risiko yang paling tinggi. Hal ini ditunjukkan dari nilai standar deviasi yang bernilai tinggi yaitu 0.037603 . Dilakukan pengujian distribusi normal terhadap return ketiga saham dengan uji Kolmogorv Smirnov.

Tabel 2 Pengujian Distribusi Normal Return Saham

\begin{tabular}{lrr}
\hline \multicolumn{1}{c}{ Saham } & $\mathrm{D}_{\text {hitung }}$ & P-Value \\
\hline Return AMAG & 0,147 & $<0,010$ \\
Return LPGI & 0,310 & $<0,010$ \\
Return PNIN & 0,199 & $<0,010$ \\
\hline
\end{tabular}

\section{b.Pemodelan ARMA-GARCH}

Syarat stasioneritas dibedakan menjadi dua jenis, yaitu stasioner dalam mean dan stasioner dalam varians. Uji stasioner data dapat menggunakan uji Augmented Dickey Fuller (ADF). Berikut adalah hasil uji ADF return saham AMAG, LPGI, dan PNIN.

Tabel 3 Hasil Augmented Dickey Fuller

\begin{tabular}{ccrr}
\hline Saham & T & Lag Order & P-Value \\
\hline AMAG & $-11,073$ & 12 & 0,01 \\
LPGI & $-14,417$ & 12 & 0,01 \\
PNIN & $-11,513$ & 12 & 0,01 \\
\hline
\end{tabular}

Dapat disimpulkan bahwa data return saham AMAG, LPGI, dan PNIN telah stasioner dalam mean. Selanjutnya pemodelan dilakukan dengan melakukan identifikasi model pada plot ACF dan PACF, kemudian melakukan estimasi parameter model ARMA-GARCH pada masing-masing return saham perusahaan. Tabel 4 adalah hasil estimasi model return saham AMAG.

Tabel 4 Model ARMA Return Saham AMAG

\begin{tabular}{ccrrc}
\hline Model & Par & Estimasi & $\mathbf{t}_{\text {hitung }}$ & P-value \\
\hline ARMA & $\phi_{7}$ & 0,73859 & 5,01 & $<0,0001$ \\
$([7],[7])$ & $\theta_{7}$ & 0,68385 & 4,29 & $<0,0001$ \\
\hline
\end{tabular}


Tabel 4 menunjukkan model ARMA yang memiliki parameter signifikan untuk perusahaan AMAG adalah ARMA([7],[7]) dengan $P$-value kurang dari $\alpha$ sebesar 0,05 , sehingga didapatkan model sebagai berikut.

$$
r_{t}=0,73859 r_{t-7}+a_{t}-0,68385 a_{t-7}
$$

Pada pemodelan GARCH dilakukan pula identifikasi plot ACF dan PACF yang didapatkan dari residual kuadrat model ARMA yang terbentuk. Berikut estimasi parameter model GARCH yang disajikan pada Tabel 5.

Tabel 5 Model ARMA Return Saham AMAG

\begin{tabular}{ccrrr}
\hline Model & Par & Estimasi & $\mathbf{t}_{\text {hitung }}$ & P-value \\
\hline & $\omega$ & 0,0000859 & 13,90 & $<0,0001$ \\
GARCH (1,2) & $\alpha_{1}$ & 0,1581 & 17,72 & $<0,0001$ \\
& $\beta_{1}$ & 0,1030 & 2,33 & 0,0198 \\
& $\beta_{2}$ & 0,6513 & 15,70 & $<0,0001$
\end{tabular}

Berdasarkan Tabel 5 model GARCH yang memiliki parameter signifikan untuk perusahaan AMAG adalah GARCH $(1,2)$. Hal ini diketahui berdasarkan $P$-value kurang dari $\alpha$ sebesar 0,05 , sehingga didapatkan model sebagai berikut.

$$
\sigma_{t}^{2}=0,0000859+0,1030 \sigma_{t-1}^{2}+0,6513 \sigma_{t-2}^{2}+0,1581 a_{t-1}^{2}
$$

Dengan cara yang sama dilakukan estimasi parameter seperti pada Tabel 4 untuk model ARMA dan Tabel 5 untuk model GARCH. Didapatkan hasil semua parameter telah signifikan pada masingmasing return saham perusahaan, maka dapat ditulis model ARMA-GARCH untuk masing-masing return saham perusahaan adalah sebagai berikut.

LPGI mendapatkan model yang signifikan adalah ARMA ([2],[2]) GARCH $(1,1)$ berdasarkan hasil estimasi parameter yang telah dilakukan. Berikut adalah model untuk perusahaan LPGI.

ARMA ([2],[2]) : $r_{t}=0,76301 r_{t-2}+a_{t}-0,8093 a_{t-2}$

$\operatorname{GARCH}(1,1): \sigma_{t}^{2}=0,000701+0,2941 \sigma_{t-1}^{2}+0,2478 a_{t-1}^{2}$

Kemudian didapatkan model untuk PNIN berdasarkan hasil estimasi parameter yang telah dilakukan adalah ARMA (0,[3]) GARCH $(1,2)$. Berikut adalah model untuk perusahaan PNIN.

$\operatorname{ARMA}(0,[3]): r_{t}=a_{t}-0,07103 a_{t-3}$

$\operatorname{GARCH}(1,2): \sigma_{t}^{2}=0,0000488+0,1106 \sigma_{t-1}^{2}+0,6207 \sigma_{t-1}^{2}+0,2004 a_{t-1}^{2}$

\section{c. Pemodelan Parsimony ARMA-GARCH}

Pemodelan yang dilakukan pada sebelumnya dijelaskan dengan tanpa memperhatikan model Parsimony. Dilakukan pula pemodelan return masing-masing saham perusahaan dengan menggunakan model Parsimony. Sama halnya dengan langkah pada model sebelumnya, langkah pertama adalah mengidentifikasi plot ACF dan PACF untuk mendapatkan beberapa dugaan model ARMA. Setelah dilakukan identifikasi, langkah selanjutnya adalah mengestimasi parameter pada model ARMA pada masing-masing return saham perusahaan. Tabel 6 merupakan hasil estimasi model return saham AMAG.

Tabel 6 Model ARMA Return Saham AMAG

\begin{tabular}{ccccc}
\hline Model & Par & Estimasi & $\mathbf{t}_{\text {hitung }}$ & P-value \\
\hline $\begin{array}{c}\text { ARMA } \\
(1,0)\end{array}$ & $\phi_{1}$ & -0.06114 & -2.58 & 0.0099 \\
\hline
\end{tabular}

Model ARMA pada Tabel 6 yang memiliki parameter signifikan adalah model ARMA $(1,0)$ karena $P$-value kurang dari $\alpha$ sebesar 0,05 , sehingga model ARMA $(1,0)$ adalah sebagai berikut.

$$
r_{t}=-0.06114 r_{t-1}
$$

Pemodelan selanjutnya adalah pemodelan GARCH yang didapatkan identifikasi plot ACF dan PACF dari residual kuadrat. Berikut adalah estimasi parameter model GARCH pada perusahaan AMAG.

Tabel 7 Model ARMA Return Saham AMAG

\begin{tabular}{ccccc}
\hline Model & Par & Estimasi & $\mathbf{t}_{\text {hitung }}$ & P-value \\
\hline
\end{tabular}




\section{Endy Normacinthya Damayanti, Heri Kuswanto}

\begin{tabular}{ccrrr} 
& $\omega$ & 0,0000703 & 14,85 & $<0,0001$ \\
GARCH & $\alpha_{1}$ & 0,1101 & 16,36 & $<0,0001$ \\
$(1,1)$ & $\beta_{1}$ & 0,8165 & 83,48 & $<0,0001$ \\
\hline
\end{tabular}

Estimasi parameter yang ditunjukkan pada Tabel 7 dapat diketahui bahwa $P$-value kurang dari $\alpha$ sebesar 0,05 , sehingga parameter telah signifikan secara statistik. Model Parsimony GARCH $(1,1)$ dapat dikatakan sebagai model terbaik untuk return saham AMAG dengan model sebagai berikut.

$$
\sigma_{t}^{2}=0,0000703+0,8165 \sigma_{t-1}^{2}+0,1101 a_{t-1}^{2}
$$

Dengan cara dan langkah yang sama dilakukan estimasi parameter dan pengujian parameter seperti Tabel 6 untuk mendapatkan model Parsimony ARMA dan Tabel 7 untuk mendapatkan model Parsimony GARCH. Sehingga didapatkan model ARMA-GARCH untuk masing-masing saham perusahaan adalah sebagai berikut.

Berdasarkan hasil estimasi parameter yang telah dilakukan, saham perusahaan LPGI mendapatkan model Parsimony yang signifikan adalah ARMA $(0,1)$ GARCH $(1,1)$. Berikut adalah model untuk saham perusahaan LPGI.

$\operatorname{ARMA}(0,1): r_{t}=a_{t}-0,06195 a_{t-1}$

$\operatorname{GARCH}(1,1): \sigma_{t}^{2}=0,000703+0,2976 \sigma_{t-1}^{2}+0,2439 a_{t-1}^{2}$

Didapatkan model Parsimony yang signifikan pada perusahaan PNIN adalah ARMA $(1,1)$ GARCH $(1,1)$. Berikut model Parsimony perusahaan PNIN.

ARMA $(1,1): r_{t}=0,54751 r_{t-1}+a_{t}-0,66365 a_{t-1}$

$\operatorname{GARCH}(1,1): \sigma_{t}^{2}=0,0000386+0,8056 \sigma_{t-1}^{2}+0,1373 a_{t-1}^{2}$

\section{d.Perhitungan Value at Risk dengan Pendekatan ARMA-GARCH}

Estimasi risiko return saham perusahaan AMAG, LPGI, dan PNIN menggunakan pendekatan ARMA-GARCH dengan kuantil sebesar 5\%. Estimasi risiko dilakukan pada model Parsimony hal ini dilakukan karena pada model Parsimony karena model GARCH yang didapatkan hampir tidak jauh berbeda antara model non Parsimony. Pada perhitungan VaR diasumsikan bahwa model ARMAGARCH telah memenuhi asumsi residual distribusi normal. Berikut adalah hasil asumsi residual distribusi normal model non Parsimony dan Parsimony sesuai model terbaik GARCH masing-masing dengan uji Kolmogorov Smirnov.

Tabel 8 Uji Asumsi Residual Distribusi Normal

\begin{tabular}{llcr}
\hline Saham & \multicolumn{1}{c}{ Model } & D & P-Value \\
\hline \multirow{2}{*}{ AMAG } & ARMA ([7],[7]) GARCH $(1,2)$ & 0,118 & $<0,010$ \\
& ARMA (1,0) GARCH $(1,1)$ & 0,124 & $<0,010$ \\
\multirow{2}{*}{ LPGI } & ARMA ([2],[2]) GARCH $(1,1)$ & 0,258 & $<0,010$ \\
& ARMA (0,1) GARCH $(1,1)$ & 0,258 & $<0,010$ \\
\multirow{2}{*}{ PNIN } & ARMA (0,[3]) GARCH $(1,2)$ & 0,139 & $<0,010$ \\
& ARMA (1,1) GARCH $(1,1)$ & 0,122 & $<0,010$ \\
\hline
\end{tabular}

Berikut ini merupakan perhitungan estimasi VaR dengan pendekatan ARMA-GARCH return saham perusahaan AMAG dengan model ARMA $(1,0)$ GARCH $(1,1)$.

Estimasi risiko pada AMAG pada Tabel 9 menjelaskan bahwa dengan pendekatan ARMAGARCH, jika investor menanamkan modalnya pada t ke 1799 (1 Mei 2017) sebesar Rp 1.000.000.000,- pada perusahaan AMAG dengan tingkat keyakinan 95\%, maka investor akan mengalami kerugian maksimum sebesar Rp 47.089.529,-

Tabel 9 Estimasi Risiko AMAG dengan VaR Pendekatan ARMA- GARCH

\begin{tabular}{cccc}
\hline$r_{t}$ & $\sigma_{t}^{2}$ & $\mathrm{VaR}(95 \%)$ & Loss \\
\hline 0,002477817 & 0,000902451 & $-0,047089529$ & $-47,089,529$ \\
\hline
\end{tabular}

Perhitungan VaR $(95 \%)=r_{t}+Z_{\alpha} \sigma_{t}$

$$
\begin{aligned}
& =0,002477817+\left(-1,65(0,000902451)^{1 / 2}\right) \\
& =-0,047089529
\end{aligned}
$$


Loss $\quad=\mathrm{VaR}(95 \%) \times$ Besar Investasi

$=-0,047089529 \times \mathrm{Rp} 1.000 .000 .000,-$

$=\operatorname{Rp} 47.089 .529,-$

Selanjutnya adalah perhitungan estimasi VaR return saham perusahaan LPGI dengan ARMA $(0,1)$ GARCH $(1,1)$. Berdasarkan Tabel 10, apabila investor menanamkan modal sebesar Rp 1.000.000.000,- pada t ke 1799 (1 Mei 2017) dengan tingkat keyakinan 95\% pada perusahaan LPGI, maka investor akan mengalami kerugian sebesar Rp 62.018.734,-

Perhitungan $\mathrm{VaR}(95 \%)=r_{t}+Z_{\alpha} \sigma_{t}$

$$
\begin{aligned}
& =0,000017612+\left(-1,65(0,001413593)^{1 / 2}\right) \\
& =-0,062018734 \\
\text { Loss } & =\operatorname{VaR}(95 \%) \times \text { Besar Investasi } \\
& =-0,062018734 \times \operatorname{Rp} 1.000 .000 .000,- \\
& =\operatorname{Rp} 62.018 .734,-
\end{aligned}
$$

Tabel 10 Estimasi Risiko LPGI dengan VaR Pendekatan ARMA- GARCH

\begin{tabular}{cccc}
\hline$r_{t}$ & $\sigma_{t}^{2}$ & $\mathrm{VaR}(95 \%)$ & Loss \\
\hline 0,000017612 & 0,001413593 & $-0,062018734$ & $-62,018,734$ \\
\hline
\end{tabular}

Terakhir adalah perhitungan estimasi VaR pada return saham perusahaan PNIN dengan ARMA $(1,1)$ GARCH $(1,1)$ sebagai berikut.

Perhitungan VaR $(95 \%)=r_{t}+Z_{\alpha} \sigma_{t}$

$$
\begin{aligned}
& =0,001016828+\left(-1,65(0,000593982)^{1 / 2}\right) \\
& =-0,03919654 \\
\text { Loss } & =\text { VaR }(95 \%) \times \text { Besar Investasi } \\
& =-0,03919654 \times \operatorname{Rp} 1.000 .000 .000,- \\
& =\operatorname{Rp} 39.196 .540,-
\end{aligned}
$$

Perhitungan nilai risiko disajikan pada Tabel 11. Pada tabel tersebut dijelaskan bahwa dengan tingkat keyakinan 95\%, seorang investor akan mengalami kerugian maksimum sebesar Rp 39.196.540,- jika ia menanamkan modal sebesar Rp 1.000.000.000,- pada t ke 1799 (1 Mei 2017).

Tabel 11 Estimasi Risiko PNIN dengan VaR Pendekatan ARMA- GARCH

\begin{tabular}{cccc}
\hline$r_{t}$ & $\sigma_{t}^{2}$ & $\mathrm{VaR}(95 \%)$ & Loss \\
\hline 0,001016828 & 0,000593982 & $-0,03919654$ & $-39,196,540$ \\
\hline
\end{tabular}

\section{KESIMPULAN DAN SARAN}

\section{A. Kesimpulan}

Berdasarkan hasil analisis dan pembahasan pada data return harian saham AMAG, LPGI, dan PNIN diperoleh kesimpulan sebagai berikut.

1. Ketiga saham perusahaan memberikan nilai rata-rata return yang positif sehingga dapat dikatakan bahwa ketiga perusahaan memberikan keuntungan bagi investor. Saham perusahaan LPGI memiliki potensi risiko yang paling tinggi karena nilai standar deviasi yang tinggi dan ketiga saham tersebut tidak berdistribusi normal.

2. Pemodelan ARMA-GARCH secara non-parsimony pada return saham AMAG, LPGI, dan PNIN dapat diperoleh bahwa model ARMA terbaik untuk return saham AMAG adalah ARMA ([7],[7]) dan model GARCH terbaik adalah GARCH $(1,2)$. Pada saham LPGI diperoleh model ARMA terbaik adalah ARMA ([2],[2]) dan model GARCH terbaik adalah GARCH $(1,1)$. Saham terakhir yaitu saham PNIN diperoleh model ARMA terbaik adalah ARMA $(0,[3])$ dan model GARCH terbaik adalah GARCH $(1,1)$. Pemodelan ARMA-GARCH secara parsimony pada return saham AMAG diperoleh model terbaik ARMA $(1,0)$ GARCH $(1,1)$ dan return saham LPGI diperoleh model terbaik ARMA $(0,1)$ GARCH $(1,1)$. Terkahir pada return saham PNIN diperoleh model terbaik ARMA $(1,1)$ GARCH $(1,1)$.

3. Perhitungan Value at Risk dengan pendekatan ARMA-GARCH parsimony didapatkan investor akan mengalami kerugian maksimum sebesar Rp 47.089.529,- apabila investor menanamkan 
modalnya sebesar Rp 1.000.000.000,- pada perusahaan AMAG di waktu ke 1799 (1 Mei 2017), begitu pula pada perusahaan LPGI, seorang investor akan mengalami kerugian maksimum sebesar Rp 62.018.734,-. Pada perusahaan PNIN seorang investor akan mengalami kerugian sebesar Rp 39.196.540,- apabila menanamkan modalnya sama pada kedua perusahaan yang lain pada tingkat keyakinan $95 \%$.

\section{B. Saran}

Hasil perhitungan estimasi risiko menggunakan metode VaR dengan pendekatan ARMAGARCH masih menghasilkan asumsi residual yang tidak berdistribusi normal, maka dapat disarankan untuk dapat menghitung estimasi risiko menggunakan metode $\mathrm{VaR}$ untuk asumsi yang tidak berdistribusi normal. Selain menggunakan metode tersebut, dapat juga untuk mengatasi asumsi residual yang tidak berdistribusi normal dengan metode lain, salah satunya adalah Copula GARCH yang tidak memerlukan asumsi normalitas bersama dan dapat menangkap tail dependence diantara masing-masing variabel.

\section{Daftar Pustaka}

[1] Chandra, R., 2010. Analisis Pemilihan Saham oleh Investor Asing di Bursa Efek Indonesia. Bisnis\&Birokrasi, Jurnal Ilmu Administrasi dan Organisasi, 101.

[2] Simorangkir, E.,2016. October 03). Detik Finance [On-Line] Dikutip 15 Maret 2017. Retrieved from Detik.com: m.detik.com/finance

[3] Almawadi, I., 2017. Di Tengah Dominasi Perbankan, Saham Asuransi Ini Sudah Naik Lebih Dari 100\% [On-Line] 2 Juni 2017. Retrieved from Bareksa: www.bareksa.com.

[4] Nastiti, K. L.,2012. Analisis Volatilitas Saham Perusahaan Go Public dengan Metode ARCHGARCH. Jurnal Sains dan Seni ITS, 259.

[5] Wei, W. W., 2006. Time Series Analysis: Univariate and Multivariate Methods, Second Edition. New York: Pearson.

[6] Gujarati, D. N.,2004. Basic Econometrics, Fourth Edition. The Mcgraw: Hill Companies.

[7] Cryer, J. D., \& Chan, K. S.,2008. Time Series Analysis with Applications in R. Second Edition. New York: Springer.

[8] Bowerman, B. L., \& O'Connell, R. T.,1993. Forecasting and Time Series: An Applied Approach, edition. Belmont. California: Duxbury Press.

[9] Daniel, W. W.,1989. Statistik Nonparametrik Terapan. Jakarta: PT. Gramedia

[10] Manganelli, S., \& Engle, R. F. (2001). Value at Risk Models in Finance. Working Paper no 75 Wuropean Central Bank (ECB) Germany.

[11] Chan, N. H., \& Wong, H. Y.,2015. Simulation Techniques in Financial Risk Management, Second Edition. Hoboken: New Jersey: John Wiley \& Sons Inc. 